Journal of Engineering and Applied Sciences 15 (6): 1351-1358, 2020

ISSN: 1816-949X

(C) Medwell Journals, 2020

\title{
A Methodology for Selecting and Prioritizing Suitable Criteria for Sustainability Assessment of the Buildings and Development of Iran's Sustainable Building Rating System (ISBRS)
}

\author{
Ehsan Niksefat and Katayon Taghizade \\ Department of Architecture, Faculty of Fine Arts, University of Tehran, Tehran, Iran
}

\begin{abstract}
Iran's energy intensity in 2013 was four times the global average. The construction sector is responsible for about $40 \%$ of this consumption and the average energy consumption per square meter of the building isn't good compared to other countries. Today, the green building rating systems, as a method of environmental assessment of buildings has developed significantly. In line with promoting green building standards, these systems are of significant help for designers and builders and therefore, their usage has been increased day by day. However, selection of suitable criteria and weighting them is one of the challenges for developing and using these systems. This choice without considering the climatic conditions, the geographic location and the environmental priorities isn't possible. Hence, the development of regional ranking systems, comparing to international systems is of great importance. In this study with the aim of achieving a rating system in accordance with climatic conditions and environmental restrictions of our country, at first a comprehensive study on the available ranking systems have been done. Then among existing system, 6 of them including LEED, BREEAM, Pearl, GPRS, QSAS and SEAM have been selected and their criteria were categorized. Then by removing the similar criteria, a basket of 133 criteria is derived which is then divided into 11 groups. Afterwards, by forming a team of experts and performing a deep interview, a basket of 68 modified indexes in 8 areas was obtained. Then, by using the AHP technique and Expert-Choice Software, categories were compared and weighted. By calculating the coefficient of incompatibility, the comparison results are verified. We compared the proposed rating model, called Iran sustainable building rating system with the six other ranking systems and the obtained results are analyzed and the benefits of the system are discussed. At the end, we discuss our suggestions for the promotion and future development of the system.
\end{abstract}

Key words: Green building, sustainable building rating systems, green building rating tools, promotion, compared, calculating

\section{INTRODUCTION}

Nowadays, there are many agencies that have introduced tools or systems to evaluate the sustain ability of buildings that are known as sustainable building assessment tools or sustainable building rating systems. All of them have considered some criteria for sustain ability assessment and for each criteria, due to its importance and effectiveness, separate components are considered. Project assessor considers certain scores for criteria. From the sum of the scores of each criteria (is usually estimated based on 100), the total score of the project is obtained and shows the level of project success in observing sustain ability criteria. These tools help project managers to have a true understanding of the project condition. First, these tools were created as energy efficiency assessment tools or green building rating tools. Over time and with the development of public interest, environmental and economic aspects were considered, too. Terms such as sustainable construction, sustainable building and sustainable architecture were considered in this area. The most common tools for building's sustain ability assessment were BREEAM (Building Research Establishment Environmental Assessment Method) IEL. (2012), LEED (Leadership in Energy and Environmental Design), CASBEE (Comprehensive Assessment System for Built Environment Efficiency) and Green Srat and DGNB (Deutsche Gesellschaft für nachhaltiges Bauen-German Sustainable Building), respectively. Kibert (2013) enumerated some of these green building assessment tools in his book. The use of rating tools was started by vertical buildings and gradually moved toward horizontal buildings and transportation sector. Among the suitable tools for infrastructure projects, CEEQUAL (Civil Engineering Environmental Quality Assessment and Award Scheme) can be pointed out that started its services in 2003 in England. Studies five tools that have the most applicability in infrastructure projects. 
These tools are as follows: BE2ST-IN-HIGHWAYS (Building Environmentally and Economically Sustainable Transportation-Infrastructure-Highways (BE2ST-Inhighways); Envision (Envision, developed by the Zofnass Program for Sustainable Infrastructure based at the Harvard Graduate School of Design and the Institute for Sustainable Infrastructure (ISI) http://www.asce.org/ envision/); Green LITES (Green Leadership in Transportation and Environmental Sustainability); I-LAST (Illinois Livable and Sustainable Transportation); INVEST (Infrastructure Voluntary Evaluation Sustainability Tool). Numerous studies have been conducted on the development or promotion of sustainable building rating systems. Table 1 , provides a summary of the previous studies in this area.
Problem description: Since, 1989 with the advent of the first assessment tool called BREEAM in England the type, weight and number of criteria for sustain ability assessment of buildings have changed constantly. Also, there were disagreements about how the criteria should be selected. There were concerns about the problems of these tools in several studies that were proposed by several critics. Priorities related to sustainable development are different in various countries. In some countries such as China, air pollution is the most important case. In Iran, dust, air pollution and shortage of water are the critical cases.

Neama (2012) mention the specific and general criteria in their study and affirm that the priorities in Middle East are different than in Europe and America and thus their local criteria are different (Neama, 2012). For example, as pointed in LEED system, the creation of facilities for bicycle in the building is advantageous while

Table 1: Six sustainable building rating systems

\begin{tabular}{|c|c|}
\hline References & Title \\
\hline Bo Xia in 2014 & Sustainable construction trends in journal \\
\hline $\begin{array}{l}\text { Yamany et al. } \\
\text { in } 2016\end{array}$ & $\begin{array}{l}\text { Applicability and Implementation of US } \\
\text { Green Building Council rating system } \\
\text { (LEED) in Egypt }\end{array}$ \\
\hline $\begin{array}{l}\text { Nguyen and Altan } \\
\text { in } 2011\end{array}$ & $\begin{array}{l}\text { Comparative review of five sustainable } \\
\text { rating systems }\end{array}$ \\
\hline Ammar in 2012 & Evaluation of the Green Egyptian Pyramid \\
\hline Xia et al. in 2015 & $\begin{array}{l}\text { Comparison of sustainable community } \\
\text { rating tools in Australia }\end{array}$ \\
\hline Alyami (2015) & $\begin{array}{l}\text { The development of sustainable } \\
\text { assessment method for Saudi Arabia } \\
\text { built environment: weighting system }\end{array}$ \\
\hline $\begin{array}{l}\text { Nguyen and Altan } \\
\text { in } 2011\end{array}$ & $\begin{array}{l}\text { TPSI (Tall-Building Project Sustainability } \\
\text { Indicator) }\end{array}$ \\
\hline
\end{tabular}

Publication

Sharifi and Murayam A critical review of seven selected in 2013 neighborhood sustainability assessment tools

Asdrubali et al. in 2015

Wu et al. in 2016

Banihashemi et al. in 2014
A comparison between environmental sustainability rating systems LEED and ITACA for residential buildings A decade review of the credits obtained by LEED v2.2 certified green building projects

Managerial sustainability assessment tool for Iran's building
Description

During 2000-2012, 743 articles were published in 12 journals.

From these, 48 articles were published in technical journals. The author states that the articles are published in these seven areas: sustainable project management; sustainability assessment sustainable technology; sustainable building; government policies about sustainability Investment sustainability; Sustainability education

Three buildings in Egypt that received LEED proposed suggestions. One of the important points in this regard is that in Egypt in addition to LEED, GPRS is used as a local rating system

Five rating systems were studied and some criteria were investigated in this regard. Some suggestions were proposed regarding these systems

GPRS system of Egypt was compared with other systems in other countries and some suggestions were provided

Three rating systems in Australia were studied and differences and similarities were investigated

Using AHP, the criteria and weights were enumerated and finally, SEAM was proposed for Saudi Arabia

14] An accurate investigation on existing rating systems such as BREEAM, LEED, GB Tool, CASBEE and HK-Beam were performed and a new rating system called TPSI was introduced. The new system was only applicable for tall buildings. Besides showing its advantages, they explained how it can be implemented [15] Seven neighborhood sustainability systems including LEED-ND, Earth Craft assessment tools Communities (ECC), BREEAM, communities, CABEE-UD, HQE2R, ecocity and SCR which are related to Australia, Europe, Japan and United States of America were investigated. The advantages and disadvantages of each system were explained

[16] LEED and ITACA were studied. First, two systems were introduced and then, buildings were assessed using these s ystems. Finally, advantages and disadvantages were enumerated

[17] A decade of LEED V2.2 performance was investigated. More than, 5000 projects were assessed using this version of LEED. The author presented some recommendations for proper use of this system

[18] Various systems were studied and some criteria were proposed for design, construction and operation steps. Then, the Satbir rating system proposed for assessment of sustainability in Iran's buildings 
in a tropical zone like Saudi Arabia, the use of bicycle does not make sense. The Middle East countries are faced by the shortage of water and need cooling facilities. On the other hand, these countries have huge energy sources. Also, European and North American countries suffer from the shortage of energy. Moreover, they have cold weather and need warming devices. That means any region of the world will have specific credits which measure the environmental priorities and challenges. Besides, it will have some general credits that serve the global challenges. In Agenda 21 is has been pointed out that sustainable construction adopts different approaches and is accorded different priorities in different countries (CIB., 1999). In recent changes in LEED (ver.4), regional priority with the score of 4 is seen and this shows that importance of this issue that regional and local priorities are more determined for these systems. Maybe, one reason that different countries are looking for specific rating system is the attention toward local and regional criteria's. Authors investigated several rating systems using interview and questionnaire and showed that local systems, due to specific criteria, local systems have better performance compared to international systems (Saaty, 1980).

\section{MATERIALS AND METHODS}

The research process has been depicted in Fig. 1. Data collection method and tools consisted of interview and AHP technique (Saaty, 1980). The Expert Choice Software was used for criteria comparison. We used the quantitative analysis technique to analyze the interviews.

Preparing a basket of criteria: At first, a comprehensive study was performed on the various green (sustainable) building ratings systems. From different systems, 6 systems were studied according to Table 2. LEED and BREEAM as international systems with high popularity and other regional systems that are consistent with climatic conditions of Iran were selected.

At first, 285 criteria were selected and after eliminating the similar criteria and also criteria which included two or more other criteria, 133 criteria was remained and classified into 11 categories. For example, in Table 3 and 4, a comparison between the criteria between "water efficiency" and "energy" that are selected can be seen. Each system that has emphasized a certain criteria is indicated in the table.

Interview with experts: At this step, an expert panel is used to select criteria. This panel was randomly selected and in addition to interview with experts, the following questions were answered:

Which of the extracted criteria, considering climatic conditions and priorities is suitable for sustainable building rating system in Iran? (The expert panel rate the criteria in the range of 1-5. Number one indicates that the criterion is not appropriate, 2 indicates that the criterion

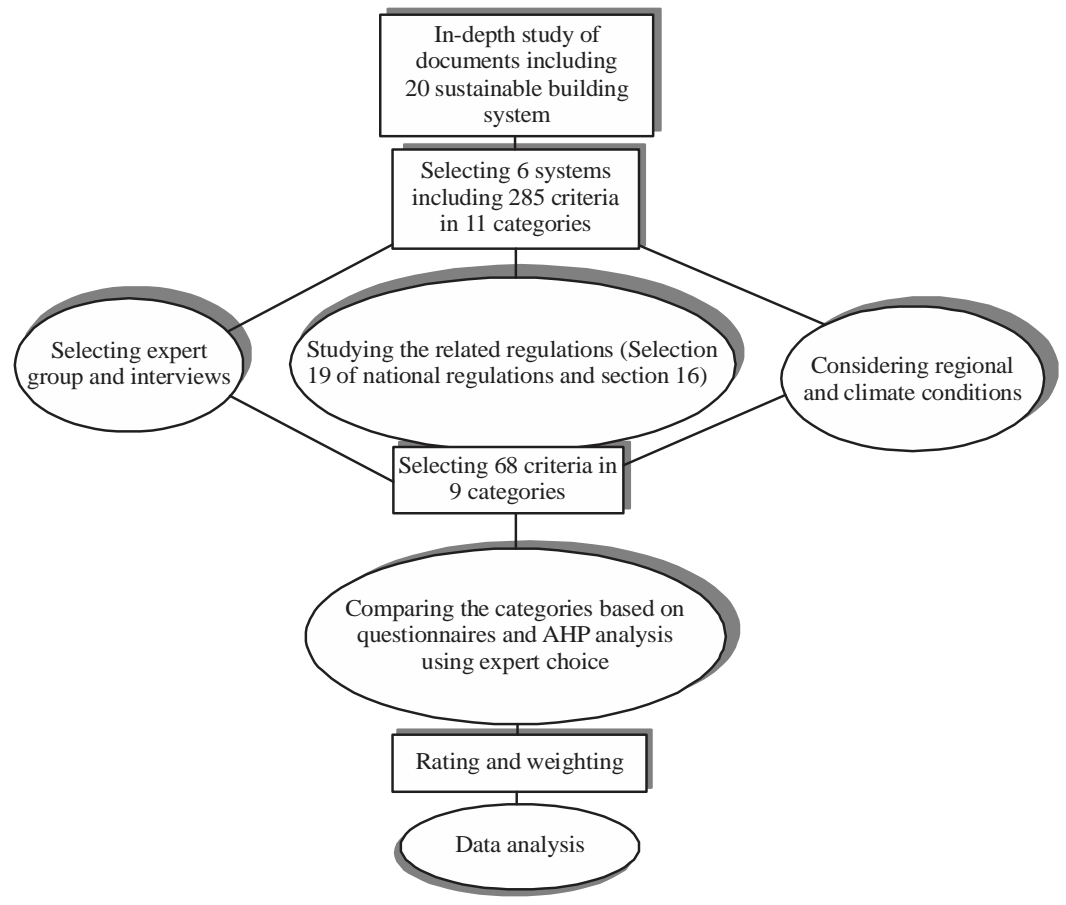

Fig. 1: Research method framework 
J. Eng. Applied Sci., 15 (6): 1351-1358, 2020

Table 2: Six sustainable building rating systems

\begin{tabular}{|c|c|c|c|c|c|c|}
\hline Reference & Pearl & QSAS & $\begin{array}{l}\text { GPRS } \\
\text { (NRCI) }\end{array}$ & $\begin{array}{l}\text { SEAM } \\
\text { (Alyami, 2015) }\end{array}$ & $\begin{array}{l}\text { BREEAM-UK } \\
\text { (IEL., 2012) }\end{array}$ & $\begin{array}{l}\text { LEED-NC } \\
\text { (USGBC) }\end{array}$ \\
\hline System & $\begin{array}{l}\text { The pearl rating } \\
\text { system for Estidama }\end{array}$ & $\begin{array}{l}\text { Qatar Sustainability } \\
\text { Assessment System }\end{array}$ & $\begin{array}{l}\text { Green Pyramid } \\
\text { Rating System }\end{array}$ & $\begin{array}{l}\text { Saudi Environmental } \\
\text { Assessment Method }\end{array}$ & $\begin{array}{l}\text { Building Research } \\
\text { Establishment } \\
\text { Environmental } \\
\text { Assessment Method }\end{array}$ & $\begin{array}{l}\text { Leadership in Energy } \\
\text { and Environmental } \\
\text { Design }\end{array}$ \\
\hline Country & UAE & Qatar & Egypt & Saudi Arabia & England & USA \\
\hline Developer & $\begin{array}{l}\text { Abu Dhabi Urban } \\
\text { Planning Council }\end{array}$ & $\begin{array}{l}\text { Barwa and Qatari } \\
\text { Diar Research } \\
\text { Institute (BQDRI) }\end{array}$ & LEED & $\begin{array}{l}\text { Saleh Alyami; } \\
\text { Cardiff University }\end{array}$ & $\begin{array}{l}\text { Building Research } \\
\text { Establishment (BRE) }\end{array}$ & $\begin{array}{l}\text { US Green Building } \\
\text { Council }\end{array}$ \\
\hline Year & 2010 & 2010 & 2010 & 2014 & 1990 & 2000 \\
\hline Version & 1 & 1 & 1 & 1 & 2008 & 4 \\
\hline Developed from & ----- & $\begin{array}{l}\text { CASBEE Green } \\
\text { Globes SBTool } \\
\text { BREEAM LEED } \\
\text { CEPAS }\end{array}$ & LEED & $\begin{array}{l}\text { LEED BREEAM } \\
\text { Green Globes GPRS } \\
\text { Pearl }\end{array}$ & Primary & Primary \\
\hline Benchmarks & $\begin{array}{l}1 \text { pearl mandatory } \\
2 \text { pearl: } 60 \\
3 \text { pearl: } 85 \\
4 \text { pearl: } 115 \\
5 \text { pearl: } 145\end{array}$ & 1-6 Star & $\begin{array}{l}\text { Certified: } 40 \\
\text { Silver: } 50 \\
\text { Gold: } 60 \\
\text { Green: } 80\end{array}$ & $\begin{array}{l}\text { Unclassified } \\
\text { Pass: } 35 \\
\text { Bronze: } 45 \\
\text { Silver: } 55 \\
\text { Gold: } 75 \\
\text { Diamond: } 85\end{array}$ & $\begin{array}{l}\text { Pass: } 30 \\
\text { Very good: } 55 \\
\text { Excellent: } 70 \\
\text { Outstanding: } 85\end{array}$ & $\begin{array}{l}\text { Certified: } 40 \\
\text { Silver: } 50 \\
\text { Gold: } 60 \\
\text { Platinum: } 80\end{array}$ \\
\hline
\end{tabular}

Table 3: Comparing the criteria of water efficiency group in rating systems

\begin{tabular}{|c|c|c|c|c|c|c|}
\hline Water efficiency & LEED & BREEAM & Pearl & GPRS & QSAS & SEAM \\
\hline Water use reduction & $\sqrt{ }$ & $\sqrt{ }$ & $\sqrt{ }$ & $\sqrt{ }$ & $\sqrt{ }$ & $\sqrt{ }$ \\
\hline Water use monitoring & $\sqrt{ }$ & $\checkmark$ & $\sqrt{ }$ & $\sqrt{ }$ & & \\
\hline Water efficient equipment & & $\checkmark$ & & & & \\
\hline Water leakage detection & & $\checkmark$ & $\sqrt{ }$ & $\checkmark$ & & \\
\hline Cooling tower water & $\sqrt{ }$ & & & $\checkmark$ & & \\
\hline Grey water recycling & $\checkmark$ & & & & & $\checkmark$ \\
\hline Collecting the rain water & $\checkmark$ & & $\checkmark$ & $\checkmark$ & & $\sqrt{ }$ \\
\hline Irrigation system & & & & & & $\checkmark$ \\
\hline Decreased water consumption for cooling the air & & & $\checkmark$ & & & \\
\hline Water features efficiency & & & $\sqrt{ }$ & & & \\
\hline
\end{tabular}

Table 4: Comparison of energy efficiency criteria in rating systems

\begin{tabular}{|c|c|c|c|c|c|c|}
\hline Energy efficiency & LEED & BREEAM & Pearl & GPRS & QSAS & SEAM \\
\hline Minimum energy performance & $\sqrt{ }$ & $\checkmark$ & $\sqrt{ }$ & $\sqrt{ }$ & $\sqrt{ }$ & \\
\hline Energy monitoring & $\sqrt{ }$ & $\checkmark$ & $\sqrt{ }$ & $\checkmark$ & $\checkmark$ & $\sqrt{ }$ \\
\hline Building envelope performance & & & & & & $\sqrt{ }$ \\
\hline HVAC system & & $\sqrt{ }$ & & & & $\sqrt{ }$ \\
\hline Hot water system & & & & & & $\sqrt{ }$ \\
\hline Energy management system & & & & & & $\sqrt{ }$ \\
\hline Intelligent building control system & & & & & $\checkmark$ & \\
\hline Renewable energy technology & $\sqrt{ }$ & $\sqrt{ }$ & $\sqrt{ }$ & $\sqrt{ }$ & & $\sqrt{ }$ \\
\hline Ozone impacts of refrigerants & $\sqrt{ }$ & $\sqrt{ }$ & $\sqrt{ }$ & $\sqrt{ }$ & & \\
\hline Energy efficient appliances & & $\sqrt{ }$ & $\sqrt{ }$ & $\sqrt{ }$ & & \\
\hline Demand response & $\sqrt{ }$ & & & & & \\
\hline Peak load reduction & & & $\sqrt{ }$ & $\checkmark$ & & \\
\hline Facility maintenance & & & & $\sqrt{ }$ & & $\sqrt{ }$ \\
\hline Vertical transportation systems & & $\sqrt{ }$ & $\sqrt{ }$ & $\sqrt{ }$ & & \\
\hline Drying space & & $\sqrt{ }$ & & & & \\
\hline Fossil fuel conservation & & & & & $\checkmark$ & \\
\hline Shading strategy & & & & & & $\checkmark$ \\
\hline $\mathrm{CO}_{2}$ emission & & & & $\sqrt{ }$ & $\sqrt{ }$ & \\
\hline NOx and SOx emission & & $\sqrt{ }$ & & $\sqrt{ }$ & $\sqrt{ }$ & \\
\hline Building user guide & & & & $\sqrt{ }$ & & \\
\hline Energy monitoring during construction & & $\checkmark$ & & & & \\
\hline Leak detection & & & & & $\checkmark$ & \\
\hline Exterior lighting & & $\sqrt{ }$ & & & & \\
\hline
\end{tabular}

is not important and 3-5 indicate the amount of importance from low to high). Do you thing a new criteria can be added to the list?. Therefore, by extracting criteria that their mean was larger than 2.5 is list including 68 criteria in 8 categories was obtained that is depicted in Table 5. The average degree of importance in shown in column 1 and the score of the criteria is shown in column 2. "Location", “ecology” and "transportation" 
J. Eng. Applied Sci., 15 (6): 1351-1358, 2020

Table 5: Classification and prioritization of criteria according to the experts

\begin{tabular}{|c|c|c|c|c|c|c|c|c|}
\hline $\begin{array}{l}\text { Location, ecology } \\
\text { and transportation }\end{array}$ & Expert & Points & Water efficiency & Expert & Points & Materials and wastes & Expert & Points \\
\hline $\begin{array}{l}\text { Development in rated } \\
\text { and prioritized } \\
\text { communities }\end{array}$ & 2.6 & 1 & Water use reduction & 4.9 & 3 & Green materials & 4.4 & 3 \\
\hline $\begin{array}{l}\text { Brown field site } \\
\text { redevelopment }\end{array}$ & 2.8 & 1 & Water use monitoring & 4.7 & 3 & $\begin{array}{l}\text { Responsible sourcing } \\
\text { of material }\end{array}$ & 4.2 & 3 \\
\hline Historical areas & 2.9 & 1 & Water leakage detection & 3.2 & 2 & Insulation & 2.6 & 1 \\
\hline $\begin{array}{l}\text { Compatibility with national } \\
\text { development plan }\end{array}$ & 3.1 & 2 & Gray water & 4.5 & 3 & Local materials & 4.3 & 3 \\
\hline Proximity to amenities & 4.3 & 3 & Collecting the rain water & 4.6 & 3 & $\begin{array}{l}\text { Materials appropriate } \\
\text { with climate }\end{array}$ & 2.5 & 1 \\
\hline $\begin{array}{l}\text { Protection of plant and } \\
\text { animal habitats }\end{array}$ & 3.3 & 2 & Irrigation system & 2.8 & 1 & $\begin{array}{l}\text { Construction waste } \\
\text { management }\end{array}$ & 5.0 & 3 \\
\hline $\begin{array}{l}\text { Protection of environment } \\
\text { against construction pollution }\end{array}$ & 3.5 & 2 & $\begin{array}{l}\text { Indoor environment } \\
\text { quality }\end{array}$ & & & Recycling facilities & 2.3 & 1 \\
\hline $\begin{array}{l}\text { Preservation, amendment } \\
\text { and development of vegetation }\end{array}$ & 4.6 & 3 & $\begin{array}{l}\text { Indoor air quality during } \\
\text { construction and operation }\end{array}$ & 3.6 & 2 & $\begin{array}{l}\text { Operational waste } \\
\text { management }\end{array}$ & 3.5 & 2 \\
\hline Greenhouse heating effect & 2.6 & 1 & Natural ventilation & 3.8 & 2 & Prefabricated elements & 4.6 & 3 \\
\hline Desertification & 2.7 & 1 & Visual comfort & 4.8 & 3 & Materials reuse & 4.3 & 3 \\
\hline Contaminated lands & 2.8 & 1 & Thermal comfort and control & 4.6 & 3 & building reuse & 3.1 & 2 \\
\hline $\begin{array}{l}\text { Access to transportation } \\
\text { network }\end{array}$ & 4.8 & 3 & Water quality & 2.7 & 1 & Recycled materials & 4.8 & 3 \\
\hline Bicycle facilities & 3.2 & 2 & Acoustic comfort & 4.8 & 3 & Design for material reduction & 2.5 & 1 \\
\hline Car parking capacity & 4.2 & 3 & Low emitting materials & 4.9 & 3 & Modular systems & 2.7 & 1 \\
\hline Electrical or hybrid cars & 2.5 & 1 & Smoke control & 3.9 & 2 & Historical and cultural aspects & & \\
\hline Energy efficiency & & & Security and safety & 2.6 & 1 & Cultural and historical identity & 3.1 & 2 \\
\hline $\begin{array}{l}\text { Minimum energy } \\
\text { performance }\end{array}$ & 5.0 & 3 & Air tightness of building & 5.0 & 3 & $\begin{array}{l}\text { Habits and customs effects } \\
\text { (prevent dust) }\end{array}$ & 2.6 & 1 \\
\hline $\begin{array}{l}\text { Energy monitoring } \\
\text { and reporting }\end{array}$ & 4.9 & 3 & Day lighting & 3.1 & 2 & Constancy of Islamic faith & 2.7 & 1 \\
\hline $\begin{array}{l}\text { Intelligent building } \\
\text { control system }\end{array}$ & 2.4 & 1 & Outdoor noise pollution & 4.1 & 3 & Management and operation & & \\
\hline $\begin{array}{l}\text { Renewable energy } \\
\text { technology }\end{array}$ & 4.8 & 3 & External lighting & 2.6 & 1 & $\begin{array}{l}\text { Contribution of advisors and } \\
\text { constructors in green or } \\
\text { sustainable rating }\end{array}$ & 4.1 & 3 \\
\hline $\begin{array}{l}\text { Ozone impacts of } \\
\text { refrigerants }\end{array}$ & 3.8 & 2 & Quality views & 3.1 & 2 & $\begin{array}{l}\text { Commissioning and } \\
\text { decommissioning strategy }\end{array}$ & 3.6 & 2 \\
\hline Energy efficient appliances & 4.7 & 3 & & & & Procurement path & 2.5 & 1 \\
\hline $\begin{array}{l}\text { Vertical transportation } \\
\text { systems }\end{array}$ & 3.1 & 2 & & & & $\begin{array}{l}\text { Committed and responsible } \\
\text { stakeholders }\end{array}$ & 2.6 & 1 \\
\hline Drying space & 2.4 & 1 & & & & Operation and maintenance & 2.7 & 1 \\
\hline Shading strategy & 2.5 & 1 & & & & Inno & & \\
\hline NOx and SOx emission & 3.7 & 2 & & & & Innovating practice & 4.8 & 3 \\
\hline
\end{tabular}

categories were separated and finally were integrated in "site aspect". Also, “materials" and “wastes" were integrated, too.

Prioritizing and weighting of categories: After selecting the criteria, prioritization and weighting should be taken into consideration Trusty (2008) believes that distributing and weighting the criteria is one of the most complicated parts of each system. One method to compare several criteria is AHP. To prioritize the selection criteria and determining their importance level, numerous studies have used the same method (Wong and Li, 2007). In this study, this method has been used for distribution of points and weights at the second level.

The experts were asked to prioritize and compare the aspects in 8 different categories. In Saaty method Saaty
(1980), the comparisons are rating by $1 / 9$ to 9 where 9 indicate the highest degree compared to other criteria and $1 / 9$ shows the lowest priority degree.

In this questionnaire, the importance between two parameters is rated between 1 and 9. Here, 1 means equality, 3 means moderate priority, 5 means strong priority, 7 means very strong priority and 9 means extreme priority. Also, 2, 6 and 8 show moderate priorities. In the following, the obtained matrix was analyzed by Expert Choice.

In Fig. 2, this matrix that has been made in the software can be seen. Each component is obtained from the mean of experts comments. Fig. 3 is another outcome of the software. As can be seen, "energy efficiency", "water efficiency", "materials" and "wastes" with the scores of 23, 15 and 14 from 100 are three priorities of a sustainable building from the perspective of experts. 


\begin{tabular}{|c|c|c|c|c|c|c|c|c|c|c|c|c|c|c|c|c|c|c|c|}
\hline \multicolumn{20}{|c|}{ Circle one number row below using the scale: } \\
\hline & Water effuciency & 9 & 8 & 7 & 6 & 5 & 4 & 3 & 2 & 1 & 2 & 3 & 4 & 5 & 6 & 7 & 8 & 9 & Site aspect \\
\hline & Water effuciency & 9 & 8 & 7 & 6 & 5 & 4 & 3 & 2 & 1 & 2 & 3 & 4 & 5 & 6 & 7 & 8 & 9 & Energy efficiency \\
\hline & Water effuciency & 9 & 8 & 7 & 6 & 5 & 4 & 3 & 2 & 1 & 2 & 3 & 4 & 5 & 6 & 7 & 8 & 9 & Indoor environment \\
\hline & Water effuciency & 9 & 8 & 7 & 6 & 5 & 4 & 3 & 2 & 1 & 2 & 3 & 4 & 5 & 6 & 7 & 8 & 9 & Material and waste \\
\hline & Water effuciency & 9 & 8 & 7 & 6 & 5 & 4 & 3 & 2 & 1 & 2 & 3 & 4 & 5 & 6 & 7 & 8 & 9 & Management and oper \\
\hline & Water effuciency & 9 & 8 & 7 & 6 & 5 & 4 & 3 & 2 & 1 & 2 & 3 & 4 & 5 & 6 & 7 & 8 & 9 & Cultural aspect \\
\hline & Water effuciency & 9 & 8 & 7 & 6 & 5 & 4 & 3 & 2 & 1 & 2 & 3 & 4 & 5 & 6 & 7 & 8 & 9 & Inovation \\
\hline & Site aspect & 9 & 8 & 7 & 6 & 5 & 4 & 3 & 2 & 1 & 2 & 3 & 4 & 5 & 6 & 7 & 8 & 9 & Enery efficiency \\
\hline & Site aspect & 9 & 8 & 7 & 6 & 5 & 4 & 3 & 2 & 1 & 2 & 3 & 4 & 5 & 6 & 7 & 8 & 9 & Indoor environment \\
\hline & Site aspect & 9 & 8 & 7 & 6 & 5 & 4 & 3 & 2 & 1 & 2 & 3 & 4 & 5 & 6 & 7 & 8 & 9 & Material and waste \\
\hline 11 & Site aspect & 9 & 8 & 7 & 6 & 5 & 4 & 3 & 2 & 1 & 2 & 3 & 4 & 5 & 6 & 7 & 8 & 9 & Management and oper \\
\hline 12 & Site aspect & 9 & 8 & 7 & 6 & 5 & 4 & 3 & 2 & 1 & 2 & 3 & 4 & 5 & 6 & 7 & 8 & 9 & Cultural aspect \\
\hline & Site aspect & 9 & 8 & 7 & 6 & 5 & 4 & 3 & 2 & 1 & 2 & 3 & 4 & 5 & 6 & 7 & 8 & 9 & Inovation \\
\hline & Energy effuciency & 9 & 8 & 7 & 6 & 5 & 4 & 3 & 2 & 1 & 2 & 3 & 4 & 5 & 6 & 7 & 8 & 9 & Indoor environment \\
\hline 15 & Energy effuciency & 9 & 8 & 7 & 6 & 5 & 4 & 3 & 2 & 1 & 2 & 3 & 4 & 5 & 6 & 7 & 8 & 9 & Material and waste \\
\hline & Energy effuciency & 9 & 8 & 7 & 6 & 5 & 4 & 3 & 2 & 1 & 2 & 3 & 4 & 5 & 6 & 7 & 8 & 9 & Management and oper \\
\hline 17 & Energy effuciency & 9 & 8 & 7 & 6 & 5 & 4 & 3 & 2 & 1 & 2 & 3 & 4 & 5 & 6 & 7 & 8 & 9 & Cultural aspect \\
\hline
\end{tabular}

Fig. 2: Matrix of comparison between categories (Expert Choice)

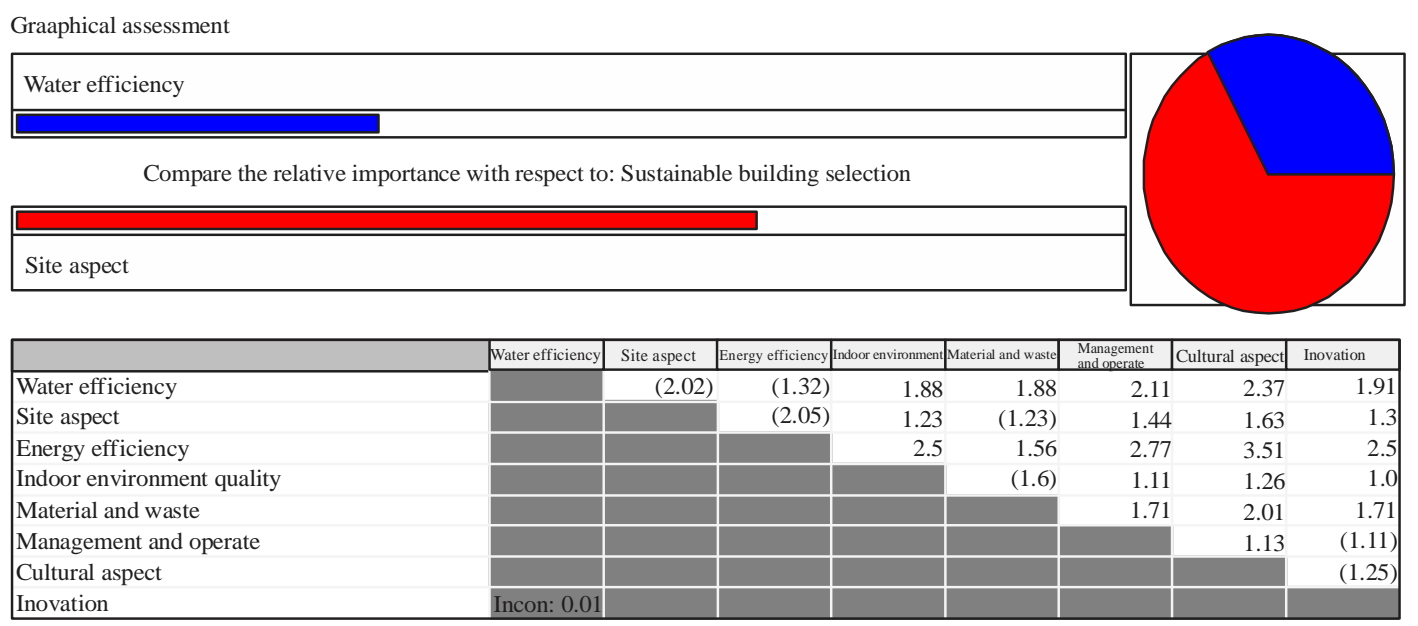

Fig. 3: Comparison of criteria (Expert Choice)

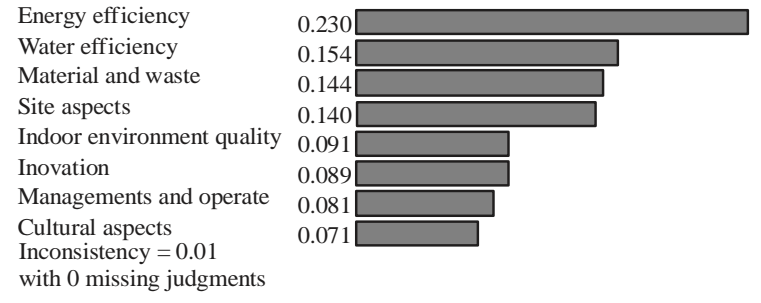

Fig. 4: Prioritization between categories (Expert Choice)

Consistency Ratio (CR): Basically, AHP method is based on pair wise comparison of options. Also, it is likely that inconsistency occurs in this comparison. For example, if $\mathrm{A}>\mathrm{B}$ and $\mathrm{B}>\mathrm{C}$, we will have $\mathrm{A}>\mathrm{C}$. Now, if $\mathrm{A}<\mathrm{C}$, we have inconsistency. In this problem, Expert Choice estimated the inconsistency coefficient as 0.01 (IR $=0.01)$ and since, it is $<0.1$, it indicates the consistency of the comparison (Fig. 4).

\section{RESULTS AND DISCUSSION}

Alyami (2015) states that the main part of a rating system is weighing. Indeed, what makes distinction between rating systems is the difference in the weight of criteria. Table 6 shows the results and priorities of sustainable building rating system in Iran as well as the scores for each category.

Table 7 presents a comparison of each criterion weight between the proposed rating system for Iran and other 6 rating systems. In the energy efficiency category,due to the high energy consumption in the building (around $40 \%$ of the total energy consumption in this part-non-productive), the energy consumption have always been attracted attention. In spite of putting too much emphasis in the section 19 of national regulations (energy saving) which is compulsory, still the amount of energy consumption per square meter of buildings in Iran 
Table 6: Point attribution method in Iran sustainable building rating system

\begin{tabular}{|c|c|c|c|c|}
\hline Category & Weight percentage & No.of criteria & Points & Description \\
\hline Energy efficiency & 23.4 & 10 & 21 & $\begin{array}{l}\text { Minimum energy performance by proper insulation and double-glazed } \\
\text { glass-boiler and generator emissions should be lower than the defined } \\
\text { level-using separate meters to measure consumption-solar energy inside } \\
\text { or outside the site-using energy efficient appliances-Intelligent control } \\
\text { methods-natural lighting-natural ventilation-a climate oriented architecture. } \\
\text { Using shading-balcony to dry clothes-using high efficiency lamps-lighting } \\
\text { control by time and movement sensor }\end{array}$ \\
\hline Water efficiency & 15.4 & 6 & 15 & $\begin{array}{l}\text { Water use reduction inside and outside the building compared to the } \\
\text { standard level-Water metering using separate meters for a 5-year period } \\
\text { after receiving the certificate-using equipment to decrease water } \\
\text { consumption-rainwater collectionsystem-reusing water for irrigation-modern } \\
\text { irrigation methods-using trees and vegetation with low need to } \\
\text { water-controlling the concentration of parameters in cooling towers }\end{array}$ \\
\hline Material and waste & 14.4 & 14 & 30 & $\begin{array}{l}\text { Using material with low environmental effects-at least, } 25 \% \text { of materials } \\
\text { should be recycled materials-local materials-reusing materials or building } \\
\text { elements-materials consistent with the environment-prefabricated } \\
\text { materials-modular design-waste management-waste separation location }\end{array}$ \\
\hline Site aspects & 14 & 15 & 27 & $\begin{array}{l}\text { Development in rated and prioritized communities-reuse of land (at least } \\
75 \% \text { of the development should not be undisturbed lands)-priority of } \\
\text { development in historical and contaminated lands -employing ecologist } \\
\text { consultant in large scale projects-preservation and development of } \\
\text { landscape-design with at least } 30 \% \text { open space-reducing the construction } \\
\text { effect on the environment-access to facilities-access to transportation } \\
\text { network-bicycle facilities-limited parking space-electrical or hybrid cars }\end{array}$ \\
\hline $\begin{array}{l}\text { Indoor environment } \\
\text { quality }\end{array}$ & 9.1 & 14 & 31 & $\begin{array}{l}\text { Air quality during construction and operation-day lighting-glare } \\
\text { Control-smoke control-low emitting materials (paints, carpet,...,) lighting } \\
\text { and thermal control-acoustic comfort-visual comfort-air tightness-water } \\
\text { quality }\end{array}$ \\
\hline Innovation & 8.9 & 1 & 3 & Using innovative techniques and policies-innovative designs \\
\hline $\begin{array}{l}\text { Management and } \\
\text { operation }\end{array}$ & 8.1 & 5 & 8 & $\begin{array}{l}\text { Cooperation with green building assessment agencies-delivery } \\
\text { Management-sustainable procurements-operation and maintenance }\end{array}$ \\
\hline Cultural aspects & $\begin{array}{r}7.1 \\
100\end{array}$ & $\begin{array}{r}3 \\
68\end{array}$ & $\begin{array}{r}4 \\
139\end{array}$ & Cultural and historical identity-habits and customs effects-Islamic faith \\
\hline
\end{tabular}

Table 7: Classification and prioritization of criteria according to the experts

\begin{tabular}{|c|c|c|c|c|c|c|c|}
\hline Category & $\begin{array}{l}\text { Pearl } \\
\text { UAE }\end{array}$ & $\begin{array}{l}\text { QSAS } \\
\text { Qatar }\end{array}$ & $\begin{array}{l}\text { GPRS } \\
\text { Egypt }\end{array}$ & $\begin{array}{c}\text { SEAM } \\
\text { Saudi Arabia }\end{array}$ & $\begin{array}{c}\text { BREEAM } \\
\text { UK }\end{array}$ & $\begin{array}{c}\text { LEED-NC } \\
\text { USA }\end{array}$ & $\begin{array}{c}\text { ISBRS } \\
\text { Iran }\end{array}$ \\
\hline Site & 17 & 17 & 14 & 5.4 & 16.4 & 23.6 & 14.0 \\
\hline Energy & 26 & 24 & 24 & 26.7 & 26.4 & 30.0 & 23.4 \\
\hline Water & 23 & 16 & 29 & 25.8 & 5.5 & 10.0 & 15.4 \\
\hline Materials & 11 & 8 & 10 & 13.2 & 18.2 & 11.8 & 14.4 \\
\hline Indoor environment quality & 15 & 14 & 10 & 12.7 & 13.6 & 14.5 & 9.1 \\
\hline Management & 6 & 8 & 10 & 9.4 & 10.9 & 0.9 & 8.1 \\
\hline Innovation & 2 & & 3 & & 9.1 & 5.5 & 8.9 \\
\hline Cultural aspect & & 13 & & 2.5 & & & 7.1 \\
\hline Economic aspect & & & & 4.3 & & & \\
\hline \multirow[t]{2}{*}{ Regional priority } & & & & & & 3.6 & \\
\hline & 100 & 100 & 100 & 100 & 100 & 100 & 100 \\
\hline
\end{tabular}

is about 2.5 times greater than the global average. Thus, according to the conducted analysis, the highest priority with the weight of $23.4 \%$ has specified for this category, showing the great importance of the energy category from the perspective of expert panel. Also, the considered criteria for the energy category in this research are much more comprehensive than the section 19 of national regulations.

The most important criteria in this section (Table 6) include "energy efficiency", 'utilization of solar energy" (unfortunately the utilization level of clean energies in Iran is less than 2\%), using "Energy efficient appliances" and "monitoring" and measuring energy consumption by different countries that all of these aspects have scores higher than 4.

In water efficiency category, since, Iran is located in dry area with low level of rainfalls, the underground water level has decreased in recent years and for this reason, we have witnessed ground settlement. Although, the major part of water consumption in Iran is related to agriculture sector, the water consumption level in household sector is two times the global average. According to the result of analysis, Iran has the second place among the criteria and has dedicated the weight of $15.4 \%$ to itself. Compared to 
other systems, Iran has water consumption about 3 times the level that has been considered by BREEAM and about 1.5 times the level that has been considered for LEED. In Saudi Arabia, this weight is considered as $25.8 \%$ and since, this country does not have any river nor lake, it is justifiable. In this section, the most important criteria that are taken into consideration by experts (scores higher than 4) include "water use reduction", "water use monitoring", "reusing water or grey water" and "reusing rainfall water" (for non-drinking purposes).

In material and waste category, it should be stated that the condition of materials and wastes is not acceptable. One of the main reasons for this condition is less attention to industrialization of buildings and lack of prefabricated buildings and modular systems. According to the experts, this category has the relative weight of 14.4. In this section, BREEAM with the score of 18.2 has gained more percentage. The most important priorities to achieve sustainable building from the perspective of experts include "green material", "responsible sourcing of material”, "local material”, "construction waste management”, "prefabricated elements" and "recycled materials".

In indoor environment quality that almost points to internal parts of the organization, appropriate lighting and comfort of residents has gained the weight of $9.1 \%$. According to Table 7, the highest scores were allocated to Pear with 15 and LEED with 14.5. The most important criteria in this category with the scores above 4 are "air tightness" of building, "material with low emission", "acoustic comfort", "visual comfort", "external noise pollution" and "thermal comfort".

The management category with the weight of $8.1 \%$ gained the 6th place and despite defining five criteria in this category, only "Contribution of advisors and constructors in sustainable rating" rating above 4. In this category, BREEAM with the weight of $10.9 \%$ allocated the greatest weight to itself compared to other systems.

\section{CONCLUSION}

The innovation category that obtained the weight of $8.9 \%$, gained the second place after BREEAM with the weight of $9.1 \%$. This section aims to introduce solutions that are not predicted in rating system as a new and innovative method and each innovations receives 2 points.

The cultural aspect that is seen in rating systems of Qatar and Saudi Arabia, the experts gave the weight of 7.1 that compared to other systems is a relative high weigh but none of the suggested criteria in this category received scores higher than 4 .

\section{RECOMMENDATIONS}

Each rating system should be assessed after 3 years. The scope of study consisted of residential buildings and for future studies, other buildings such as schools, administrative buildings, training centers and banks can be taken into consideration. The most important part of a rating system is referred to comprehensive standards that can cover these systems and review international standards of sustainable or green buildings. For example, the International green Construction Code (IgCC) and standard for the design of high-performance green building except Low-Rise Residential Buildings (ASHRAE189.1) can be pointed out. Therefore, it seems that from 22 sections of national building regulations, only 19 section (energy saving) have been emerged in energy criteria. Therefore, the development of an independent section in green or sustainable buildings area seems necessary. Rating systems require basic standards as well as assessment categories (for inspection and rating), guidelines (description of ratings, necessary certificates for each score, how to rate design and performance) and an applied guideline to implement methods and criteria of sustainable building and these aspects can be taken into consideration in future studies.

\section{REFERENCES}

Alyami, S., 2015. The development of sustainable assessment method for Saudi Arabia built environment. Ph.D Thesis, Cardiff University, Cardiff, Wales.

CIB., 1999. Agenda 21 on sustainable construction. Centraal Invorderings Bureau, Rotterdam, Netherlands.

IEL., 2012. BREEAM scheme document for new construction technical manual version: SD5073. Intertom Establishment Limited, London, England.

Kibert, C.J., 2013. Sustainable Construction: Green Building Design and Delivery. 3rd Edn., John Wiley \& Sons, Hoboken, New Jersey, USA,.

Neama, W.A.S.A., 2012. Protect the planet through sustainability rating systems with local environmental criteria-leed in the middle East. Procedia Soc. Behav. Sci., 68: 752-766.

Saaty, T.L., 1980. The Analytic Hierarchy Process: Planning, Priority Setting, Resource Allocation. 2nd Edn., McGraw-Hill International Book Co., New York, USA. isBN: 9780070543713, Pages: 287.

Trusty, W., 2008. Standards versus recommended practice: Separating process and prescriptive measures from building performance. J. ASTM. Intl., 5: $1-6$.

Wong, J.K.V. and H. Li, 2007. Application of the analytic hierarchy process (AHP) in multi-criteria analysis of the selection of intelligent building systems. Building Environ., 43: 108-125. 